\title{
In-vitro Analysis of Chenopodium murale extract for resistance against potato virus Y
}

\author{
Muhammad Bilal, Bushra Tabassum, Abdul Munim Farooq*, \\ Muhammad Tariq, Idrees Ahmad Nasir and Tayyab Hussnain \\ Center of Excellence in Molecular Biology, University of the Punjab, Lahore-Pakistan \\ *Corresponding author's email: munimfarooq@gmail.com \\ Citation
}

Muhammad Bilal, Bushra Tabassum, Abdul Munim Farooq, Muhammad Tariq, Idrees Ahmad Nasir and Tayyab Hussnain. In-vitro Analysis of Chenopodium murale Extract for resistance against potato virus Y. Pure and Applied Biology. Vol. 8, Issue 2, pp1172-1181. http://dx.doi.org/10.19045/bspab.2019.80059

\begin{tabular}{llll}
\hline \hline Received: 07/02/2018 & Revised: 10/03/2019 & Accepted: 28/03/2019 & Online First: 10/04/2019 \\
\hline
\end{tabular}

\section{Abstract}

Potato (Solanum tuberosum) is one of the largely consumed staple food crop of the world, including Pakistan. In Pakistan, potato shares a large percentage in country's agriculture GDP. In Pakistan majority of good quality virus free seed potato is imported by multinational and local seed companies. This costs a huge burden on country's economy. Potato Virus Y (PVY) belongs to Potyviridae family, severely damaging leaves of the Solanaceae family including potato. Plant lectins are the potential proteins that specifically bound and cross linked with carbohydrates and target glycans present on the cell surface of viruses through a pathway termed as lectin activation. The present in-vitro study shows the effect of lectin extracted from the seeds of Chenopodium murale against the downregulation of the $\mathrm{CP}$ (coat protein) gene of PVY. Stable interaction was found between PVY coat protein and CML insilico. Full length CP gene from PVY virus was amplified and cloned in mammalian expression vector. CML protein was purified to sub fractions through anion exchange chromatography on SP-sepharose gel. The non-cytotoxic effect and safe limit of CML extract was indicated by CC50 value. The hemagglutination activity of CML against the rabbit erythrocytes was revealed to be $35 \mu \mathrm{g} / \mathrm{ml}$. The real-time PCR revealed the anti-PVY activity of CML extract. CML extract in concentration of 30, 60 and $90 \mu \mathrm{g} / \mathrm{ml}$ was found effective against PVY CP gene in comparison with control.

Keywords: Anion Chromatography; Coat Protein gene; Haemaglutination assay; HepG2 cancer cells; Lectins extract; Potato Virus Y (PVY); SDS-PAGE

\section{Introduction}

Lectins belong to the class of sugar binding family of non-immune origin. They can recognize and reversibly bind to glycans of glycoconjugate moieties without transforming their covalent structure [1]. This binding is highly precise without needing the enzymatic activity. This property of lectins allows them to act as recognition molecules between organisms, cells and even within cells making them a significant tool in biomedical research [2]. Naturally, lectins are distributed among huge number of organisms belonging to invertebrates, vertebrates, plants, fungi, sea corals and algae. Lectins are accountable of carrying out numerous biological processes including host-pathogen interactions, cell-cell communication, cell targeting, apoptosis induction, tumor differentiation and growth. In addition to 
these, they have also been known for their distinctive antiviral, antibacterial and antifungal activities. They can also inhibit virus replication by interacting with glycoprotein envelope of certain viruses [3] Plant lectins are seen to be involved in the identification of pathogenic microorganisms. High affinity is observed in lectins, isolated from soybean, for $\beta$-glucan binding which is a powerful PAMP (Pathogen-associated molecular pattern) of Phytophthora sojae [4]. Likewise, lectin gene isolated from Arabidopsis thaliana RTM1 (Restricted Tev Movement1) is seen effective against TEV (tobacco etch virus) which is a singlestranded RNA virus from genus Potyvirus [5].

Furthermore, members of genus Potexvirus shows resistance when subjected to a jacalin type lectin gene. Resistance shown by this gene is conferred during early stages of viral infection while in case of RTM1 lectin, the resistance is observed in advanced stages of infection which implements that resistance mediated by lectin plays a vital role in the diversity of plant-virus relation [6].

Potato virus Y (PVY), a member of family Potyviridae, from genus Potyvirus [7], is the most damaging virus for most of the crops worldwide mainly for plants of Solanaceae family including Nicotiana tabacum $L$. (tobacco), Capsicum annuum L. (pepper) and Solanum tuberosum L. (potato). Symptoms of PVY starts from barely noticeable mosaic patterns, reaching to necrosis and ultimately ending at the premature death of plants [8]. Due to vegetative propagation, it is hard to overcome the PVY infection which makes the primary infection quite destructive making it consistent in several generations [9]. In Pakistan, the rate of PVY infected population is recorded to be equal to $70 \%$ [10].

RNA viruses have an outer capsid made of coat protein $(\mathrm{CP})$ in which viral genome is encapsulated. $\mathrm{CP}$ has various functional, structural and ecological roles in viral infection apart from encapsulation. CP play an important role in all phases of viral growth and distribution which includes viral genome replication, accessing cells and organs and travelling between uninfected and infected parts through biological vectors [11]. Moreover, CP is linked with an early disassembly of the parental virus while assemblage of viral progeny is noticed to be an elaborative procedure [12]. Viral CP in plants work as activators forhost defense machinery in plants to prepare the host for invading viral infection. These are considered as worthy and feasible tools to save plant from viral outbreaks and at the same time provide cheap and effective framework to use these compounds in therapeutic and other purposes. These viral production systems of plants decrease the possible hazards to human health resulted from animal based viral system [11].

Various studies have been conducted to produce highly resistant commercial varieties with increased yields, including genetic modifications of PVY CP gene or P1 gene $[9,13]$. More effective resistance is observed through gene silencing in contrast to protein mediated resistance [9]. As CP gene is associated to cause hindrance in viral uncoating, replication and translation, CPDNA of potato virus $\mathrm{Y}$ can be targeted, and its mRNA expression can be downregulated by using several knockdown strategies [8].

In Pakistan, very low resistance is observed in high yielding commercially accessible potato lines against viruses, specifically PVY (potato virus Y). Current study is aimed to outline the effect of mannose-binding lectin, isolated from seeds of Chenopodium murale, against the potato virus Y CP gene.

\section{Material and methods}

In vitro Analysis

\section{Chenopodium murale Lectin}

Chenopodium murale (L.) seeds were collected from the Botanical garden, 
University of the Punjab after the confirmation through taxonomic identification by $\mathrm{Dr}$ Zahoor Ahmad Sajid (Assistant Prof.). The seeds were grinded into the fine powder in the pestle mortar and dissolved into the $0.1 \mathrm{M}$ phosphate buffer $(\mathrm{pH}$ 7.8) with respect to $1: 5(\mathrm{w} / \mathrm{v})$. Mixture was stirred at $4^{\circ} \mathrm{C}$ for 2 hours and was passed through the cheese cloth to remove the seed debris and then centrifuged at $11000 \times \mathrm{g}$ at $4^{\circ} \mathrm{C}$ for $30 \mathrm{~min}$. Supernatant was collected and subjected to $60 \%$ ammonium sulfate precipitation. The pellet was re-dissolved in $20 \mathrm{mM}$ of phosphate buffer ( $\mathrm{pH} 7.8)$ and dialyzed through dialyzing tube (Spectra/Por RC Biotech membrane, 6-8 k MWCO, 32 $\mathrm{mm}$ flat width, $100 \mathrm{ft}$ ) against $10 \mathrm{mM}$ phosphate buffer of ph7.8 for overnight at $4^{\circ} \mathrm{C}$. The dialyzed protein was stored at $4^{\circ} \mathrm{C}$ for SDS PAGE analysis and quantitation.

Anion exchange chromatography of the dialyzed protein was performed using $Q$ sepharose (GE Healthcare) column. Column was equilibrated with $5 \mathrm{cv}$ of $50 \mathrm{mM}$ phosphate buffer ( $\mathrm{pH}$ 7.8) and then partially purified protein was loaded onto column. Protein was eluted using the $0.5 \mathrm{M} \mathrm{NaCl}$ gradient and different fractions were obtained and analyzed on SDS-PAGE. The concentration of the purified protein was quantified through Bradford method [14] and bovine serum albumin was used as a standard.

\section{Hemagglutinating activity}

The hemagglutinating activity of CML $(C$. murale Lectin) was assessed in U-shaped 96 wells microtiter plate against rabbit erythrocytes as illustrated by [15]. For this, two-fold serial dilutions were prepared of CML in PBS (phosphate buffer saline) and an equal volume of $2 \%$ erythrocyte suspension was added to it. Control was prepared by adding PBS to erythrocyte suspension. The mixtures were incubated for 1 hour at room temperature and results were noticed. Positive assay shows a red-carpet layer whereas a red button formation is seen in negative assay.

\section{Total RNA isolation from PVY infected potato plants}

PVY infected potato plants were surveyed in various regions of Punjab for sample collection. From the collected viral infected plant samples, leaves were used for the isolation of total RNA by suing TRIzol reagent method with some minor changes [16]. cDNA was synthesized through cDNA synthesis kit (Thermo Fisher, Lithuania) and stored at $-20^{\circ} \mathrm{C}$.

\section{Construction of expression plasmid}

For the construction of a plasmid, $\mathrm{CP}$ gene fragment conserved in the $\mathrm{PVY}^{\circ}$ strain was taken for primer designing using the primer3 software (http://frodo.wi.mit.edu/primer3/). Using the full length sequence of $\mathrm{CP}$ gene, (Accession \# AB295475.1) primers were designed and at 5 ' end of primers HindIII and EcoRI sites were incorporated (Table 1) so, as to carry out amplification of the full length $\mathrm{CP}$ gene. For sequencing, the obtained PCR product was first cloned into pCR2.1-TOPO (Invitrogen, USA) followed by reamplification. DNA sequencing facility of CAMB was used for sequencing of isolated $\mathrm{CP}$ gene and the sequence was submitted to NCBI (Accession \# MK130988). After gel purification of the amplified fragment, it was later inserted into the mammalian expression vector pcDNA $3.1(+)$ to attain pcDNA-CP clone.

\section{Cell culture}

Cell culture lab of CEMB, Lahore, Pakistan, provided HepG2 cancer cells, which were then grown using DMEM (Dulbecco's modified Eagle medium) including penicillin $(100 \mathrm{U} / \mathrm{ml})$, streptomycin $(100 \mathrm{ug} / \mathrm{ml})$ and Fetal bovine serum (10\%), in 5\% $\mathrm{CO}_{2}$ atm. at $37^{\circ} \mathrm{C}$. 
Table 1. Sequences of primers designed against coat protein gene of PVY used in the study

\begin{tabular}{|c|c|}
\hline \multicolumn{2}{|c|}{ CP Gene Primer Sequences } \\
\hline CP Forward & ${\text { 5'-AAGCTTATGGCAAATGACACAATCGAT- } 3^{\prime}}^{\prime}$ \\
\hline CP Reverse & 5'-GAATTCATCACCCTGCCACCTCTATC- $3^{\prime}$ \\
\hline & CP Gene Real Time Primer Sequences \\
\hline CPR Forward & $5^{\prime}$-TGTGGGTTTAGCGCGTTATG- $3^{\prime}$ \\
\hline CPR Reverse & $5^{\prime}$-GTGCCTCTCTGTGTTCTCCT-3 ${ }^{\prime}$ \\
\hline
\end{tabular}

\section{Cytotoxicity assay}

MTT (3-(4,5-dimethylthiazol-2-yl) -2,5diphenyl tetrazolium bromide) assay kit (Millipore, USA) was used for assessing proliferation and cell viability. A $100 \mathrm{ul}$ $\left(1 \times 10^{5}\right)$ of Huh-7 cells were cultured in 96 wells microtiter plate using DMEM with added penicillin $(100 \mathrm{IU} / \mathrm{ml})$, streptomycin $(100 \mathrm{ug} / \mathrm{ml})$ and $10 \%$ FBS and incubated at $37^{\circ} \mathrm{C}$ in $\mathrm{CO}_{2}$ incubator for $24 \mathrm{hrs}$. Different dilutions were prepared for CML protein, added to microtiter plate and incubated for 24 hrs. in $\mathrm{CO}_{2}$ incubator at $37^{\circ} \mathrm{C}$. Each dilution was then analyzed in three replications. Media was decanted after 24 hours and freshly prepared media (100ul) was added, supplemented with 10ul of MTT solution $(5 \mathrm{mg} / \mathrm{ml}$ in $\mathrm{PBS})$, as per manufacturer's guidelines. The plate was then incubated again at $37^{\circ} \mathrm{C}$ for 4 hours in $\mathrm{CO}_{2}$ incubator. Formazan crystals were seen in the plate wells after 24 hours which were dissolved by addition of $0.1 \mathrm{ml}$ DMSO. Optical density of formazan product was assessed through ELISA (Enzyme Linked Immunosorbent Assay) plate reader at $570 \mathrm{~nm}$ as test wavelength and $620 \mathrm{~nm}$ as reference wavelength.

Following formula was used to calculate cell viability [1]:

Percent cell viability $=\frac{\text { Test } 570 \mathrm{~nm}-630 \mathrm{~nm}}{\text { Control } 570 \mathrm{~nm}-630 \mathrm{~nm}}$ $\mathrm{x} 100$

\section{Transfection}

HepG2 cells were cultured at $1 \times 10^{6}$ cells per well in 6 wells plate. Cells were grown overnight before transfection. Transfection of the cells was carried out at 50\%-70\% confluence holding medium of $0.5 \mathrm{ml}$ per well. Cells were co-transfected with the isolated CVL, together with pcDNA-CP construct. Transfection was carried out using a transfection reagent, lipofectamine 2000 (Invitrogen, CA). For the downregulation of mRNA of pcDNA-CP, 50ng-1 $\mu \mathrm{g}$ of pcDNA$\mathrm{CP}$ was used whereas three different protein concentrations of CML were tested 25, 50 and $75 \mu \mathrm{g} / \mathrm{ml}$. Experiments were carried out in triplicate.

\section{Real-time PCR analysis}

To study real-time PCR analysis of pcDNA$\mathrm{CP}, \mathrm{mRNA}$ expression was measured using RT-PCR. TRIzol reagent (Invitrogen) was used to isolate total RNA form HepG2 cells and cDNA synthesis was performed from $1 \mu \mathrm{g}$ isolated RNA using cDNA synthesis kit (Thermo Fisher, Lithuania). Primers were chosen which could amplify a fragment size of $172 \mathrm{bp}$ from full length $810 \mathrm{bp}$ gene segment of pcDNA-CP at optimized temperature. Agarose gel (2\%) was performed to check the absence of nonspecific bands through Tm optimization. PikoReal ${ }^{\mathrm{TM}}$ Real time PCR system was used to conduct RT-PCR utilizing SYBR Green Mix (Thermo Fisher, Lithuania). cDNA was used to study the mRNA expression of CML treated pcDNA-CP. Using $\beta$-actin as control 30 cycles of RT-PCR were run. Cq values of different samples and calculated standard deviation was used to perform relative gene expression analysis. Triplicates were performed for each real-time PCR assay and PikoReal software was used to interpret the results.

\section{Results}

CML protein purification 
Anion chromatography was performed to purify CML protein using Q sepharose column (GE Healthcare) and fractions were analyzed on SDS-PAGE (Figure 1). Bands of SDS-PAGE analysis showed two chains of CML protein, one of approximately $37 \mathrm{kDa}$ and other one of $18 \mathrm{kDa}$.

Hemagglutination activity

After incubation of one hour, hemagglutination activity of CML was noticed against rabbit erythrocytes with minimum concentration of approximately 35ug/ml.

\section{Cytotoxicity assay}

MTT reagent gave purple formazan crystals with living cells due to mitochondrial succinic dehydrogenase. Cell viability can be assessed through absorbance of formazan crystals in visible region [17]. Cytotoxicity of CML against HepG2 cells has been depicted in figure 2 and its IC 50 was observed at $360 \mu \mathrm{g} / \mathrm{ml}$.

CP gene amplification and pcDNA-CP construct formation

$\mathrm{CP}$ gene was ligated in pcDNA 3.1(+) vector between HindIII and EcoRI restriction sites as shown in (Figure 3). Isolation of total RNA was done followed by cDNA synthesis and primers of $\mathrm{CP}$ gene were designed as table 1 shows. PCR was performed to amplify CP gene from PVY infected potato leaves (Figure 4) and was inserted in pcDNA $3.1(+)$ using the HindIII and EcoRI restriction sites (Figure 5).

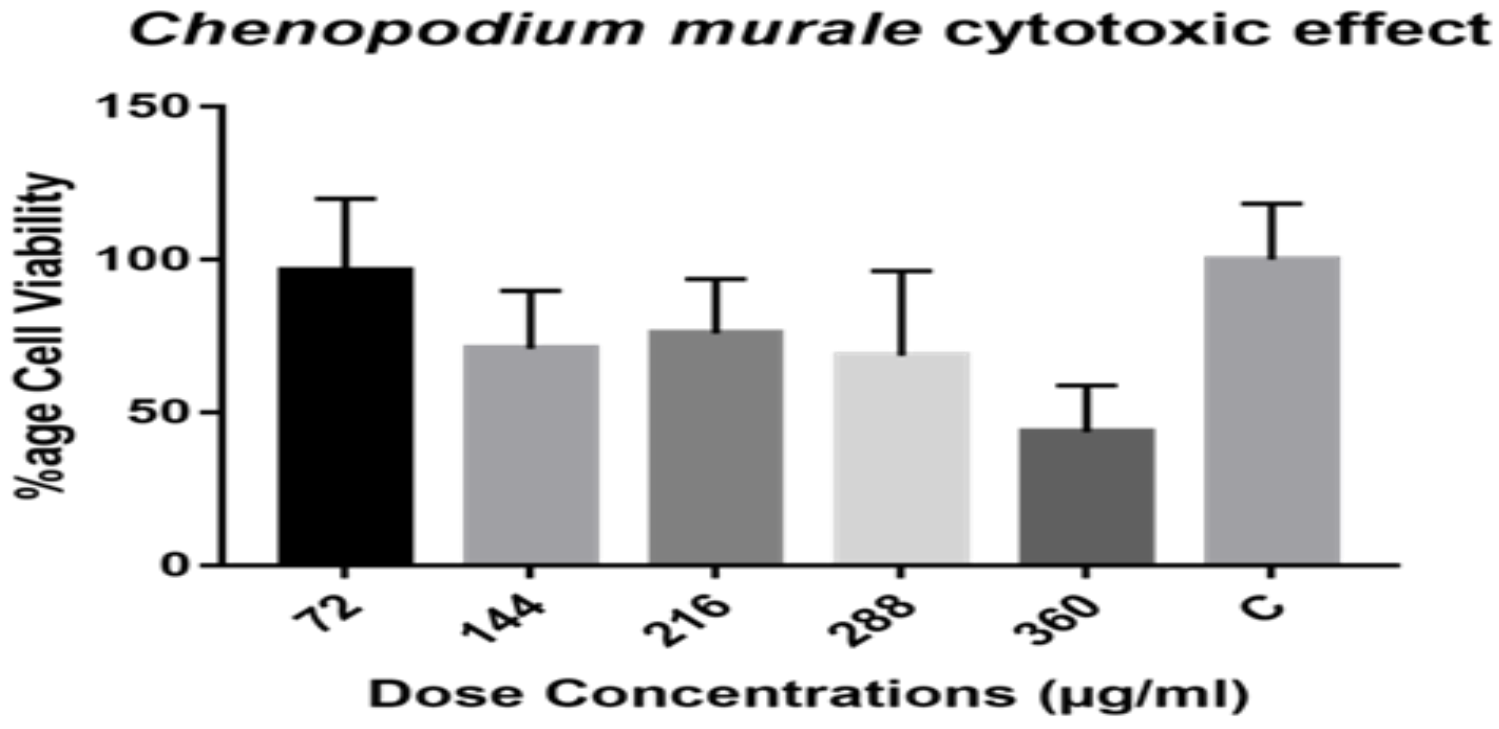

Figure 1. Shows the results of SDS PAGE. PageRuler ${ }^{\mathrm{TM}}$ Prestained Protein Ladder (Catalog number: 26616) having bands of 180, 130, 100, 70(red), 55, 40, 35, 25, 15 and $10 \mathrm{kDa}$ from top to bottom was used as a standard in well no. 1 while, well no.2 contains $60 \%$ ammonium sulfate precipitated crude protein after dialysis, well no. 3, 4 and 5 contain the fractions obtained in the anion exchange chromatography. SDS-PAGE shows two subunits of approximately 37 and $18 \mathrm{kDa}$ of the partial purified protein 


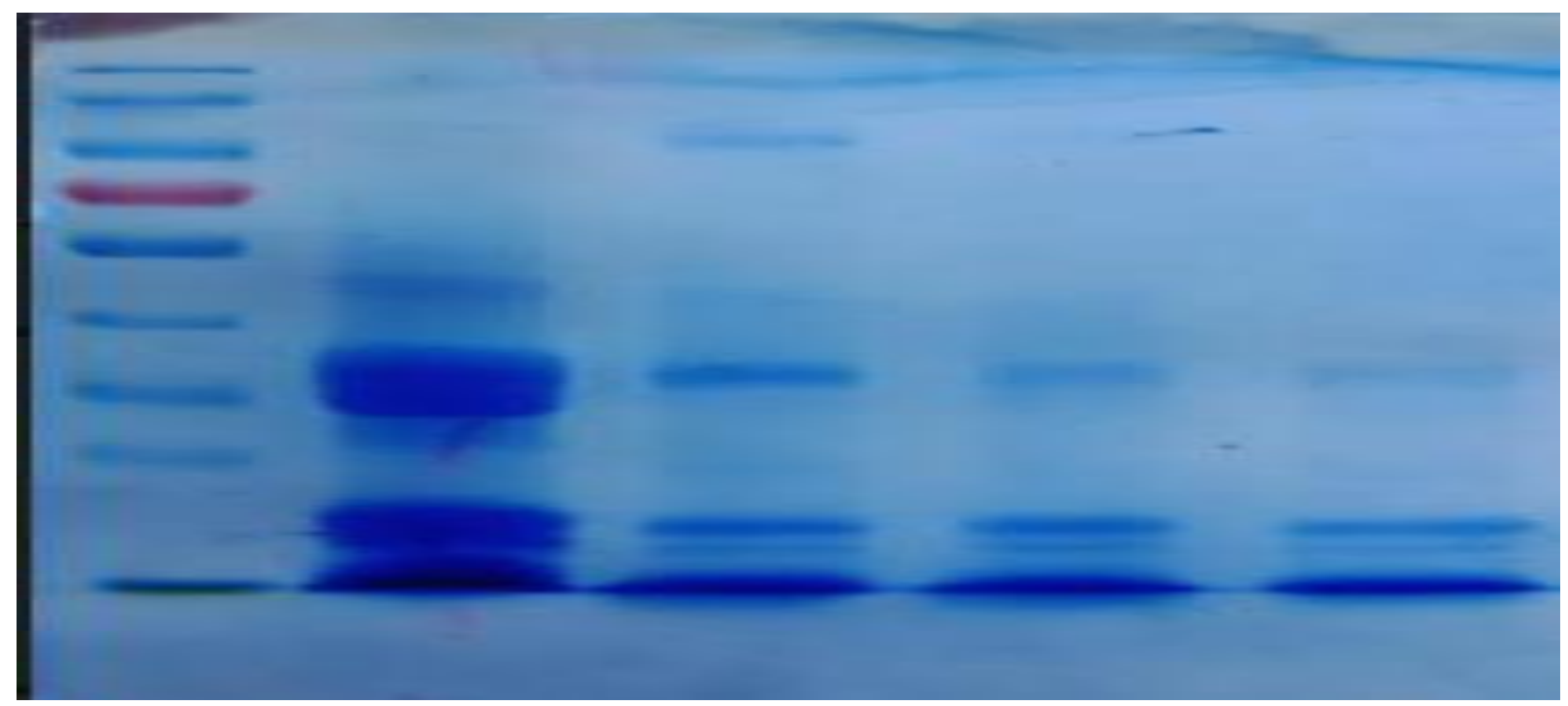

Figure 2. Cytotoxicity assay of CML to reveal safe dose limit. The dose concentration of CML purified protein extracts were ranging between $72-360 \mu \mathrm{g} / \mathrm{ml}$. Percentage cell survivals was calculated for each dose. Three biological replicated samples were processed to obtain data

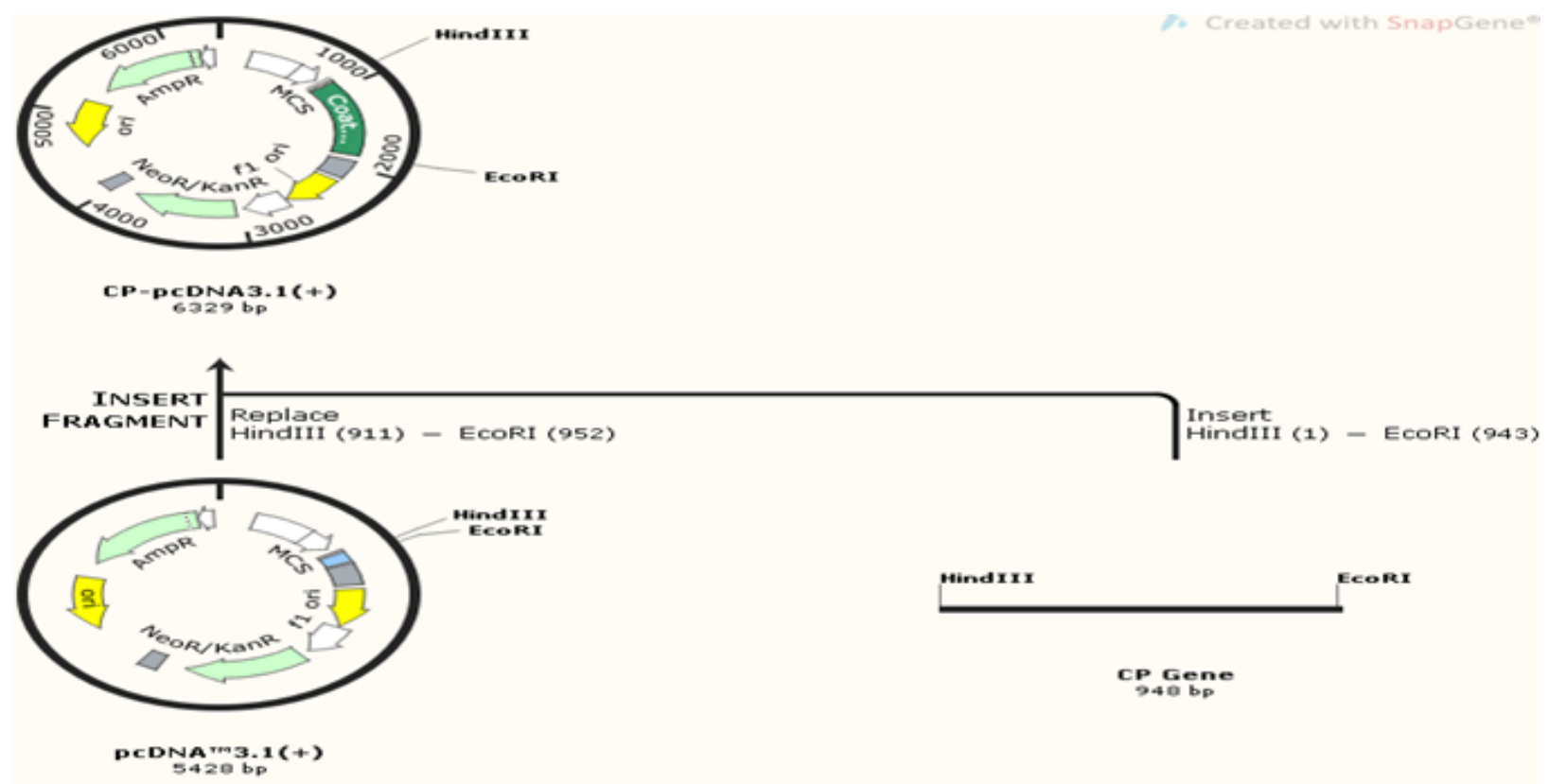

Figure 3. Map of pcDNA 3.1(+) before and after Cloning of the CP gene, Gene was cloned between HindIII and EcoRI restriction sites 

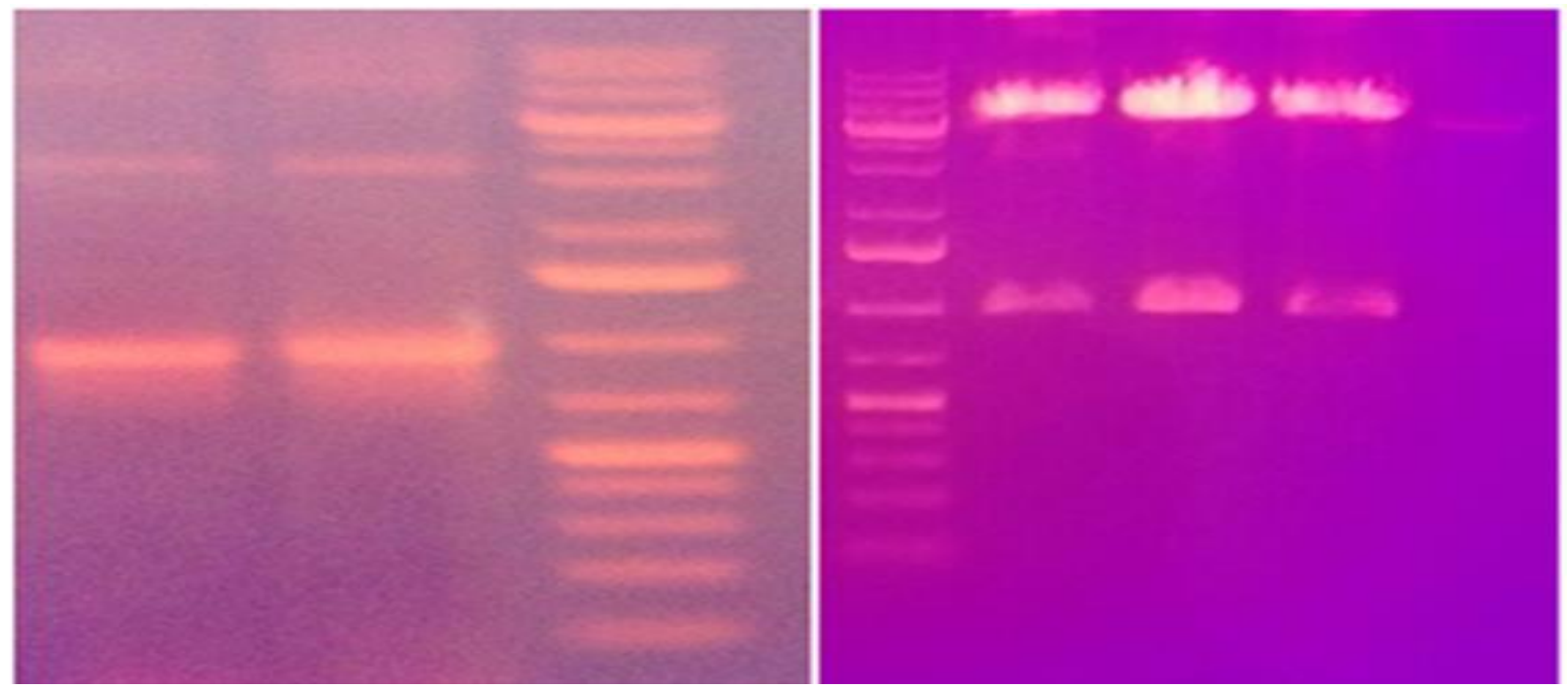

Figure 4. CP gene amplification through cDNA. Digestion of the CP gene from pcDNA3.1 (+) using the HindIII and EcoRI restriction sites

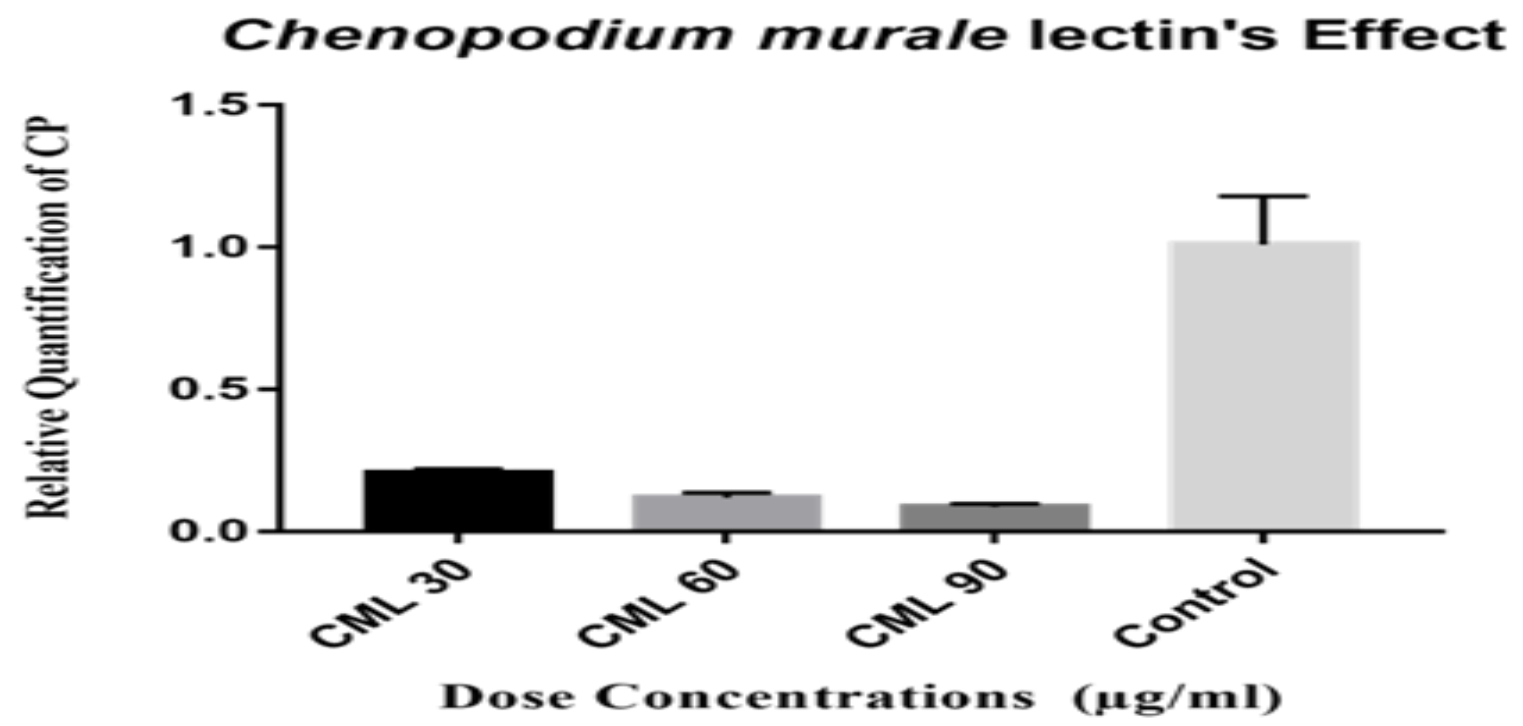

Figure 3. Anti-viral effect of CML protein on mRNA expression of PVY CP gene. Three dose concentrations of CML were tested; 30, 60 and $90 \mu \mathrm{g} / \mathrm{ml}$

pcDNA-CP mRNA is constitutively expressed in HepG2 cell lines

pcDNA-CP expression could be transiently seen in HepG2 cell line. Transfection was carried out for 24 hours using different concentrations of mammalian expression construct $p c$ DNA-CP ranging from 50ng 1ug. It was observed during transfection, $p c$ DNA-CP mRNA was constitutively expressed for initial concentration of 50ng of $p c$ DNA-CP per well. A proportional increase in mRNA expression was also seen for increased concentration of $p c$ DNA-CP. With empty vector $p c$ DNA 3.1, no expression of CP-DNA mRNA was observed in transfected or non-transfected cells.

Lipofectamine, a transfection reagent, was studies and optimized for different 
concentrations. With the use of 50ng of $p c$ DNA-CP in 6-wells culture plate, finest results were observed with 18 ul of lipofectamine per 6 wells. Conclusively, best results were found with a combination of $0.3 \mu \mathrm{g}$ of $p c \mathrm{DNA}-\mathrm{CP}$ with $18 \mathrm{ul}$ of lipofectamine in a 6 wells plate.

\section{Reduction of CP-DNA mRNA expression} by CML in HepG2 cells

Different concentrations of CML i.e. 30, 60 and $90 \mu \mathrm{g} / \mathrm{ml}$ were used to estimate downregulation of mRNA of $\mathrm{CP}$ under optimized transfection conditions (Figure 5). Isolation of total RNA from the cells coinoculated with CML, was followed by real time studies with $\mathrm{CP}$ gene primers and $\beta$ actin as reference gene or internal control. Real time analysis shows strong downregulation of mRNA of $p c$ DNA-CP.

\section{Discussion}

Potato is a chief crop worldwide and is majorly affected by Potato Virus Y (PVY). Present study is conducted to find the effect of CML on PVY CP gene. Lectins derived from different plant sources have shown strong antiviral activity for various plant viruses, so the present study focuses on isolation of CML protein from Chenopodium murale, which belongs to family Chenopodiaceae. Lectin isolated from Chenopodum quinoa have two subunits of $35 \mathrm{kDa}$ and $25 \mathrm{kDa}$ which have the ability to hemagglutinate the rabbit erythrocytes similar as described by [18]. Lectins are known to induce cytotoxicity in cancer cells by interacting with them or their receptors to produce necrosis, autophagy, apoptosis or inhibit cell growth [9].

The cytotoxicity of lectin protein named ASL 50, isolated from Allium sativum, showed no cytotoxic effect on HEK cells and human erythrocytes, but on oral carcinoma KB cells showed the cytotoxic effect and IC50 was observed as $36 \mu \mathrm{g} / \mathrm{ml}$ [20]. Different cell lines were used to estimate the inhibitory concentration of Galanthus nivalis agglutinin
(GNA). At maximum concentration of 2000 $\mathrm{ug} / \mathrm{ml}$, different percentage inhibition was noticed i.e. $0 \%$ for HeLa cell lines (Human Epithelial Cervix Carcinoma, 31\% for CEM cell lines (Human Caucasian acute leukemic lymphoblast), 31\% for FM3-A (Mouse C3H mammary carcinoma) and $23 \%$ for human $\mathrm{T}$ lymphocytes [21]. The cytotoxicity of CML was observed on HepG2 cells and it showed the IC50 near to $360 \mu \mathrm{g} / \mathrm{ml}$.

Transient expression of CP gene in mammalian cells was used as basis for adopting a particular methodology. Likewise, another study described the transfection of TMV (tobacco mosaic virus) into HeLa cells so that expression of TMV-CP gene could be generated [22]. While working with clover necrotic mosaic virus (RCNMV), plant capsid uptake and release in mammalian cells was observed [23]. Another study showed transfection of $480 \mathrm{bp}$ of CP from PVY into $\mathrm{CHO}$ cells and siRNA was used to conduct its mRNA knockdown assay [8]. Moreover, capsids of plant virus have already been used as vectors for gene delivery and expression analysis in mammals [24]. Recent studies show production of a photochemically active product when HEK293T got a successful expression of Arabidopsis cryptochrome [25].

$\mathrm{CP}$ gene is most significant in PVY studies as it causes several events including uncoating of PVY and viral RNA translation, targeting of replication site and potyvirus transmission by aphids/vectors [26]. Various studies provided strong evidence of involvement of $\mathrm{CP}$ transgene in inducing resistance in transgenic potato crops $[9,27]$. In the present study, a set of primers were used to isolate and amplify CP gene form PVY infected potato plants. A HepG2 cell line was utilized as it gives the best expression of targeted gene in almost 24 hours, additionally; full length $\mathrm{CP}$ gene was being downregulated by the CML as the dose dependent manner which clearly showed the CML can be future 
target for making the PVY resistant potato crop through transformation.

\section{Conclusion}

Conclusively, in this study we have reported the activity of lectin derived from C.murale against coat protein of potato virus Y. Invitro the purified fractions of CML exhibited strong antiviral effect against PVY. In Pakistan, this is the first report of use of CML extract to reduce antiviral activity of PVY. In future experiments the transgenic plants having lectin in potato genome could provide complete protection not only from PVY but also to other viruses.

\section{Authors' contributions}

Conceived and designed the experiments: A Munim, B Tabassum \& M Bilal, Performed the experiments: M Bilal, Analyzed the data: M Bilal \& M Tariq, Contributed materials/ analysis/ tools: AM Farooq \& M Tariq, Wrote the paper: AM Farooq.

\section{References}

1. Coelho LCBB, Silva PMDS, Lima VLDM, Pontual EV, Paiva PMG, Napoleao TH \& Correia MTDS (2017). Lectins, interconnecting proteins with biotechnological/pharmacological and therapeutic applications. Evid-Based Compl. and Alter Medic, 2017.

2. Singh RS, Kaur HP \& Singh J (2014). Purification and characterization of a mucin specific mycelial lectin from Aspergillus gorakhpurensis: application for mitogenic and antimicrobial activity. PloS one 9(10): 109265.

3. Belicky S, Katrlik J \& Tkac J (2016). Glycan and lectin biosensors. Essa. biochem 60(1): 37-47.

4. Mithofer A, Fliegmann J, Neuhaus-Url G, Schwarz H \& Ebel J (2000). The Hepta-?-Glucoside Elicitor-Binding Proteins from Legumes Represent a Putative Receptor Family. Biol chem 381(8): 705-713.

5. Whitham SA, Anderberg RJ, Chisholm ST, \& Carrington JC (2000).
Arabidopsis RTM2 gene is necessary for specific restriction of tobacco etch virus and encodes an unusual small heat shock-like protein. The Plant Cell 12(4): 569-582.

6. Yamaji Y, Maejima K, Komatsu K, Shiraishi T, Okano Y, Himeno M \& Hashimoto M (2012). Lectin-mediated resistance impairs plant virus infection at the cellular level. The Plant Cell, tpc111.

7. Kitajima EW, De Avila AC \& Resende RO (1997). Taxonomia de virus de plantas. Fitopatologia Brasileira 22(1): 5-24.

8. Tabassum B, Nasir IA \& Husnain $\mathrm{T}$ (2011). Potato virus Y mRNA expression knockdown mediated by siRNAs in cultured mammalian cell line. Virologica Sinica, 26(2): 105-113.

9. Gargouri-Bouzid R, Jaoua L, Mansour RB, Yemna H, Malika A, \& Radhouane E (2005). PVY resistant transgenic potato plants (cv Claustar) expressing the viral coat protein. J Plant Biotechnol 7(3): 1-6.

10. Abbas A \& Amrao L (2017). Potato virus $\mathrm{Y}$ : an evolving pathogen of potato worldwide. Pak J Phytopath 29(1): 187191.

11. Callaway A, Giesman-Cookmeyer D, Gillock ET, Sit TL \& Lommel SA (2001). The multifunctional capsid proteins of plant RNA viruses. Annual review of phytopathol, 39(1): 419-460.

12. Brederode FT, Linthorst HJ \& Bol JF (1991). Differential induction of acquired resistance and PR gene expression in tobacco by virus infection, ethephon treatment, UV light and wounding. Plant molecular biology17(6): 1117-1125.

13. Maki-Valkama T, Pehu T, Santala A, Valkonen JP, Koivu K, Lehto K \& Pehu E (2000). High level of resistance to potato virus $\mathrm{Y}$ by expressing $\mathrm{P} 1$ 
sequence in antisense orientation in transgenic potato. Mol Breedi, 6(1): 95104.

14. Bradford MM (1976). A rapid and sensitive method for the quantitation of microgram quantities of protein utilizing the principle of protein-dye binding. Analyt biochem, 72(1-2): 248254.

15. Ynalvez RA, Cruz CG, \&Ynalvez MA (2015). Isolation, Partial Purification and Characterization of Texas Live Oak (Quercus fusiformis) Lectin. Adv in Biosci and Biotechnol, 6(07): 470.

16. Rio DC, Ares M, Hannon GJ \& Nilsen TW (2010). Purification of RNA using TRIzol (TRI reagent). Cold Spring Harbor Protocols. 2010(6): 5439.

17. Mosmann, T (1983). Rapid colorimetric assay for cellular growth and survival: application to proliferation and cytotoxicity assays. $J$ immunol methods 65(1-2): 55-63.

18. Pompeu DG, Mattioli MA, RIBEIRO RIMDA, Goncalves DB, Magalhaes JTD, Marangoni S \& Granjeiro PA (2015). Purification, partial characterization and antimicrobial activity of Lectin from Chenopodium Quinoa seeds. Food Sci and Technol 35(4): 696-703.

19. Lei HY \& Chang CP (2009). Lectin of Concanavalin A as an anti-hepatoma therapeutic agent. $J$ biomed Sci, 16(1): 10 .

20. Kumar S, Jitendra K, Singh K, Kapoor V, Sinha M, Xess I \& Dey S (2015). Biological Properties and Characterization of ASL50 Protein from Aged Allium sativum Bulbs. Appl biochem biotechnol, 176(7): 1914-1927.
21. Balzarini J, Hatse $\mathrm{S}$, Vermeire $\mathrm{K}$, Princen K, Aquaro S, Perno CF \& Van Damme E (2004). Mannose-specific plant lectins from the Amaryllidaceae family qualify as efficient microbicides for prevention of human immunodeficiency virus infection. Antimic agents and chemoth 48(10): 3858-3870.

22. Li LI, Wang L, Xiao R, Zhu G, Li Y, Liu $C$ \& Chen L (2012). The invasion of tobacco mosaic virus RNA induces endoplasmic reticulum stress-related autophagy in HeLa cells. Biosci reports 32(2): 71-184.

23. Lockney DM, Guenther RN, Loo L, Overton W, Antonelli R, Clark J \& Franzen S (2010). The Red clover necrotic mosaic virus capsid as a multifunctional cell targeting plant viral nanoparticle. Bioconjugate chemis 22(1): 67-73.

24. Azizgolshani O, Garmann RF, CadenaNava R, Knobler CM \& Gelbart WM (2013). Reconstituted plant viral capsids can release genes to mammalian cells. Virol 441(1): 12-17.

25. Yang L, Wang X, Deng W, Mo W, Gao J, Liu Q \& Zuo Z (2016). Using HEK293T expression system to study photoactive plant cryptochromes. Front in Plant Sci 7: 940.

26. Bol JF (2008). Role of capsid proteins. In Plant Virology Protocols (pp. 21-31). Humana Press.

27. Bukovinszki A, Diveki Z, Csanyi M, Palkovics L \& Balazs E (2007). Engineering resistance to PVY in different potato cultivars in a markerfree transformation system using a 'shooter mutant'A. tumefaciens. Plant Cell Rep 26(4): 459-465. 